\title{
KAJIAN KEANGGOTAAN INDONESIA DALAM ISO/TC BIDANG INDUSTRI LOGAM, MESIN DAN ALAT ANGKUT
}

\author{
Prihadi Waluyo dan Muti Sophira Hilman
}

\begin{abstract}
In facing of the industrialization era after crisis term claim to us to be always keeping pace with the movement which could happen in the world including in the international standard. Study on the level of membership of Indonesia participation in the international standardization organization ISO/TC in the fields of metals, machines and transportation equipments industry will be one of the significant input for decision makers in phasing those situations. Technical Commmittee (TC) selection criteria use four factors involve the need of consumers, producers, government and availibility of resources, and six sub factors include import value, export value, standardization cooperation, products, natural resources and human resources. Sub committee (SC) selection criteria are derived from TC concerned. From this study, through weighting criteria approach, ten TC/ISO were chosen which involve metal products, machinery and road vehicle and suggestion for Indonesia membership based on criteria assessment for SC is P-member for 2 SC (metal product), 8 SC (machinery) and 23 SC (road vehicle), O member for 4 SC (metal product), 2 SC (machinery) and 10 SC and non member for 2 SC (machinery) and 12 SC (road vehicle).
\end{abstract}

Keywords: ISO, Technical Committee (TC), Participant member (P-member), Observer member (O-member)

\section{PENDAhULUAN}

\subsection{Latar Belakang}

Dalam era globalisasi dan perkembangan teknologi khususnya teknologi informasi dan komunikasi (ICT) menuntut kita senantiasa mengikuti perubahan yang terjadi di dunia termasuk dalam standar internasional. Melalui keanggotaan Indonesia dalam lembaga standardisasi internasional (ISO, International Organization for Standardization) c.q Komite Teknis (TC, Technical Committee), dimungkinkan untuk berpartisipasi dalam tingkat tertentu yaitu aktif ( $P$ member) dengan hak suara atas setiap rancangan standar internasional (IS) atau cukup sebagai anggota peninjau (O member) tanpa hak suara. Dengan adanya hak suara, maka kepentingan nasional bisa diperjuangkan melalui forum konsensus.

Saat ini ISO terdiri dari 2959 badan teknis dengan lebih dari 30.000 ahli terkait dengan bidang masing-masing yang tersebar pada negara-negara anggota. Sampai dengan tahun 2005, ISO telah menghasilkan 15.649 standar internasional.

Status keanggotaan Indonesia pada tahun 1999 menjadi $P$ member dalam 10 TC. Pada tahun 2000 menjadi 12 TC dan pada tahun 2001 menjadi 13 TC. Kemudian sampai saat ini (tahun 2006) aktif dalam 13 TC dan 34 SC yang ada dalam ISO.

Keanggotaan Indonesia dalam TC selama ini tidak dilakukan dengan suatu analisis yang spesifik, tetapi lebih berdasarkan pada usulan pihak tertentu, sehingga terdapat beberapa TC yang dianggap tidak merupakan prioritas bagi Indonesia tetapi pada saat ini tetap masuk daftar keanggotaan Indonesia dalam organisasi standardisasi internasional (ISO).

Sebagai contoh adalah TC 26 Fine Ceramic, Indonesia terdaftar sebagai $P$ member, namun karena tidak aktif, sesuai ketentuan ISO dalam tiga kali pengiriman berkas rancangan standar internasional berturut-turut tidak memberikan tanggapan, apakah setuju, abstain atau tidak setuju (harus disertai alasan ilmiah/argumentatif), diturunkan statusnya menjadi $O$ member dengan kehilangan hak suara.

Dalam rangka mengikuti perkembangan kegiatan dan meningkatkan keterlibatan Indonesia dalam forum standardisasi internasional, Indonesia perlu secara selektif memilih komite teknis (sektor industri) di organisasi standar internasional yang akan diikuti secara aktif sesuai dengan kebutuhan nasional. Sehingga perkembangan standardisasi internasional sektor terkait bisa diikuti dengan lebih intens, dan kepentingan Indonesia dapat terakomodasi lebih baik di forum internasional.

Masing-masing status keanggotaan tersebut akan membawa konsekuensi lebih lanjut yang perlu diperhatikan, sehingga demi efektivitas managerial perlu dikaji status keanggotaan pada suatu komite teknis internasional, apakah sebaiknya sebagai $P$ member, $O$ member, atau tidak sama sekali.

Tulisan ini tidak terlepas dengan kajian terdahulu mengenai kajian kondisi industri dan 
perdagangan produk logam, mesin dan alat angkut dalam kaitannya dengan keanggotaan Indonesia pada pada Komite Teknis dari Organisasi Standardisasi Internasial (ISO/TC). Dalam kajian tersebut diketahui bahwa produk logam, mesin dan kendaraan bermotor mempunyai trend pertumbuhan ekspor dan impor yang meningkat sehingga keikutsertaan Indonesia sebagai $P$ member dalam ISO/TC terkait perlu dipertimbangkan.

TC/ISO yang terkait logam terdapat 15 TC, TC/ISO terkait produk mesin terdapat $20 \mathrm{TC}$, dan ISO/TC terkait kendaraan bermotor terdapat 10 TC. Dari TC tersebut akan dikaji SC mana yang perlu diikuti secara aktif ( $P$ member), obsevasi ( $O$ member) dan non member. Hasil kajian ini memberikan usulan status keanggotaan Indonesia pada ISO/TC sampai pada tingkat SC, apakah $P$ member, $O$ member atau non member. Dimana usulan tersebut merupakan dasar pertimbangan untuk pembentukan Mirror Commiteee yang sesuai dengan prioritas kebutuhan Indonesia.

MC ini merupakan istilah yang digunakan ISO untuk TC nasional (untuk Indonesia, biasa disebut Panitia Teknis Perumusan SNI), yang menjadi kembaran (bayangan, mirror) dari TC/ISO. MC bertugas membantu BSN dalam mengikuti perkembangan kegiatan komite teknis internasional terkait, khususnya ISO (International Organization for Standardization), baik tingkat TC (Technical Committee), SC (Sub Committee), maupun bila perlu WG (Working Group).

\subsection{Tujuan}

Kegiatan kajian ini bertujuan untuk mencapai optimasi penentuan tingkat partisipasi keanggotaan Indonesia pada komite teknis (TC) dan Sub komite (SC) di organisasi standar internasional (ISO), melalui mirror committee.

\section{DASAR TEORI}

Di dalam masyarakat dunia yang mengarah pada globalisasi di segala bidang (khususnya industrialisasi, perdagangan bebas, profesionalisme, keterbukaan dan lingkungan hidup), ketergantungan antar negara dan antar regional telah menjadi bagian dari landasan kebijakan politik dan ekonomi di setiap negara. Keadaan ini membawa kita untuk bertindak berani, kreatif dan inofatif, meningkatkan efisiensi dan produktifitas, serta mandiri dalam rangka meningkatkan daya saing dalam menghasilkan barang/jasa yang dapat menciptakan nilai tambah optimal.
Untuk mendorong peningkatan mutu dan efesiensi industri nasional dalam menghadapi persaingan global, maka standardisasi memegang peranan penting. Hal ini diperkuat kebenarannya dengan hampir sebagian besar negara mempunyai standar nasional masingmasing serta peraturan teknisnya sendiri-sendiri.

Pengembangan ekspor terkait erat dengan perdagangan internasional yang menuntut barang/jasa yang bermutu baik dan aman bagi pemakainya serta memenuhi persyaratan keamanan, keselamatan dan kesehatan dan perlindungan fungsi lingkungan hidup serta dengan harga yang bersaing. Dalam meningkatkan dan menambah keunggulan kompetitif dalam persaingan global diperlukan pengembangan prasarana teknis untuk meningkatkan mutu barang/jasa.

Dalam perdagangan internasional pada era globalisasi dan perdagangan bebas standar dan penilaian kesesuaian menjadi perhatian utama karena jika kita kembali pada prinsip perdagangan bebas yang menghendaki transparansi terhadap perdagangan internasional maka harus ada standar yang menjadi tolok ukur transparansi tersebut.

Dalam rangka mengurangi hambatan teknis perdagangan, telah disepakati adanya perjanjian tentang Hambatan Teknis dalam Perdagangan atau "Agreement on Technical Barrier to Trade (TBT) dan World Trade Organization (WTO)". Perjanjian ini menuntut transparansi dalam perdagangan internasional, yang secara tidak langsung menuntut adanya transparansi dalam sistem standardisasi nasional yang berlaku di masing-masing negara penandatangan perjanjian tersebut.

TBT-WTO merupakan perundingan multilateral negara anggota GATT berkepentingan untuk menjamin agar standar, peraturan teknis, serta penilaian kesesuaian yang diberlakukan oleh pemerintah suatu negara tidak dipergunakan sebagai hambatan yang tidak perlu dan tidak merupakan hambatan tersembunyi dalam perdagangan internasional.

Hal-hal yang disepakati oleh negara anggota WTO antara lain adalah standar internasional digunakan sebagai dasar dalam pengembangan standar dan setiap negara anggota berperan aktif dalam penyusunan standar internasional dengan tujuan untuk harmonisasi standar. Untuk berperan aktif dalam penyusunan standar inernasional maka Indonesia harus menjadi $P$ member dari technical committee yang ada di organisasi standar internasional seperti ISO, IEC. 
Dengan keikutsertaan Indonesia dalam organisasi internasional tersebut, maka akan dapat meningkatkan sistem keberterimaan barang/jasa Indonesia ke dunia internasional karena adanya kesamaan standar yang digunakan

Dalam rangka mengikuti perkembangan kegiatan dan meningkatkan keterlibatan Indonesia dalam forum internasional, Indonesia, harus perlu secara selektif memilih komite teknis (technical committee, TC) di organisasi standar internasional yang diikuti secara aktif sesuai dengan kebutuhan nasional. Sehingga perkembangan standardisasi internasional sektor terkait bisa diikuti dengan lebih intens, dan kepentingan Indonesia dapat terakomodasi lebih baik di forum internasional.

\section{METODOLOGI PENELITIAN}

Kegiatan ini dilakukan dengan langkah sebagai berikut:

a. Mengkaji TC/SC ISO yang perlu diikuti secara aktif oleh Indonesia

\section{- Menetapkan Kriteria}

Kriteria yang ditetapkan menggunakan metode angka (point method) yang terdiri atas faktor dan sub faktor. Faktor yang dimaksud adalah konsumen, produsen, pemerintah, dan ketersediaan sumber daya. Sub Faktor yang dimaksud adalah nilai impor, nilai ekspor, kerjasama standardisasi, produk unggulan, SDA, SDM.

- Mengkaji masing-masing TC/SC ISO sesuai dengan kriteria

b. Menetapkan TC/SC ISO yang perlu diikuti secara aktif oleh Indonesia dan prioritasnya.

Penilaian terhadap TC/SC dimulai dengan TC produk, TC produk adalah TC yang terkait langsung dengan sebuah produk berupa barang. Setelah TC produk terpilih, dilakukan pemilihan SC dibawah TC terpilih tersebut.

c. Penilaian terhadap TC/SC dilakukan dengan focus group discussion dengan tenaga ahli standardisasi

Tabel 1 Kriteria Pemilihan TC

\begin{tabular}{|c|l|l|}
\hline No & \multicolumn{1}{|c|}{ Faktor } & \multicolumn{1}{c|}{ Sub Faktor } \\
\hline 1 & Kepentingan Konsumen & Nilai impor \\
\hline 2 & Kepentingan Produsen & Nilai ekspor \\
\hline 3 & Kepentingan pemerintah & Kerjasama standardisasi \\
\cline { 3 - 3 } & & Produk unggulan \\
\hline 4 & Ketersediaan sumber daya & SDA \\
\hline & & SDM \\
\hline
\end{tabular}

4. KRITERIA PEMILIHAN TC UNTUK STATUS KEANGGOTAAN INDONESIA DALAM ISO

Dalam rangka mengkaji efektifitas keanggotaan Indonesia dalam ISO/TC/SC, diperlukan suatu perangkat penilaian stakeholder nasional terhadap TC/SC tersebut. Sesuai dengan cakupan ISO, pihak-pihak yang harus dipertimbangkan dalam pembuatan standar adalah produsen, pengguna/konsumen, pemerintah, komunitas ilmiah dan masyarakat pada umumnya. Masingmasing pihak memiliki kepentingan yang berbeda sehingga harus dilakukan pembobotan untuk masing-masing kriteria.

Kriteria pemilihan TC Produk terdiri dari empat faktor yaitu tingkat kepentingan konsumen, tingkat kepentingan produsen, tingkat ke- pentingan pemerintah, serta ketersediaan sumber daya, dan sub faktor terdiri dari Nilai Impor, Nilai ekspor, Kerjasama Standardisasi, Produk Unggulan, SDA, SDM. Masing-masing faktor dan sub faktor dijelaskan sebagai berikut:

\subsection{Tingkat Kepentingan Konsumen}

Tingkat kepentingan konsumen dilihat dari jumlah konsumsi dalam negeri yang dicerminkan dengan besarnya nilai impor perdagangan. Besarnya nilai impor menunjukkan bahwa produk atau komoditi terkait dengan TC tersebut banyak di konsumsi dalam negeri. Konsumsi dimaksud dapat berupa konsumsi oleh masyarakat, instansi pemerintah maupun swasta dan industri sebagai bahan bahan baku atau bahan pendukung. 
Batasan impor dan nilai yang diberikan dapat dilihat pada Tabel 2. Data impor ini dirangkum dari mulai tahun 1999 sampai dengan 2003, atau merupakan rerata dari data 5 tahun terakhir.

\subsection{Tingkat Kepentingan Produsen}

Tingkat kepentingan produsen diindikasikan dengan besarnya nilai ekspor produk atau komoditi tersebut. Besarnya ekspor merupakan nilai yang menunjukkan besarnya produksi da- lam negeri. Artinya jika jumlah produksi besar dengan pangsa ekspor yang cukup besar, agar dapat berkompetisi dan produk tersebut memiliki keberterimaan tinggi harus selalu mengikuti standar internasional terkait.

Batasan jumlah ekspor dan nilai yang diberikan dapat dilihat pada Tabel 3. Data ekspor ini dirangkum dari mulai tahun 1999 sampai dengan 2003, atau merupakan rerata dari data 5 tahun terakhir.

Tabel 2 Penilaian Nilai Impor

(Data Rata-rata Tahun 1999 - 2003)

\begin{tabular}{|l|c|c|}
\hline No & Nilai Impor (dalam US \$ /tahun) & Nilai \\
\hline 1 & $2.000 .000 .000 X$ & 5 \\
\hline 2 & $1.000 .000 .000<=\mathrm{X}<2.000 .000 .000$ & 4 \\
\hline 3 & $500.000 .000 \quad<=\mathrm{X}<1.000 .000 .000$ & 3 \\
\hline 4 & $250.000 .00 \quad<=\mathrm{X}<500.000 .000$ & 2 \\
\hline 5 & $\mathrm{X}<250.000 .000$ & 1 \\
\hline
\end{tabular}

Tabel 3 Penilaian Nilai Ekspor

(Data Rata-rata Tahun 1999 - 2003)

\begin{tabular}{|l|c|c|}
\hline No & Nilai Ekspor (dalam US \$ /tahun) & Nilai \\
\hline 1 & $X>=6.000 .000 .000$ & 5 \\
\hline 2 & $3.000 .000 .000<=X<6.000 .000 .000$ & 4 \\
\hline 3 & $1.500 .000 .000<=X<3.000 .000 .000$ & 3 \\
\hline 4 & $750.000 .000<=X<1.500 .000 .000$ & 2 \\
\hline 5 & $X<750.000 .000$ & 1 \\
\hline
\end{tabular}

Tabel 4 Penilaian Faktor Kesesuaian dengan Kerjasama Standardisasi Internasional yang Sudah Ditandatangani

\begin{tabular}{|c|c|c|}
\hline No & Lingkup kerjasama & Nilai \\
\hline 1 & ASEAN & 5 \\
\hline 2 & APEC & 4 \\
\hline 3 & ASEM & 3 \\
\hline 4 & Bilateral & 2 \\
\hline 5 & Non & 1 \\
\hline
\end{tabular}

\subsection{Tingkat Kepentingan Pemerintah}

Pemerintah berkepentingan mengembangkan industri dalam negeri melalui pengembangan prioritas sektor pembangunan. Kebijakan ini untuk memacu perkembangan industri pada khususnya dan diharapkan akan meningkatkan kegiatan ekonomi masyarakat dan meningkatkan kesejahteraan pada umumnya. Kepentingan lain adalah menjalin kerjasama dengan negara lain baik secara bilateral, multilateral, 
regional dan internasional yang terkait khususnya dengan standardisasi dan perdagangan bebas. Kerjasama yang telah dijalin harus dikembangkan demi kepentingan nasional.

Berdasarkan hal tersebut sub faktor dari faktor tingkat kepentingan pemerintah yaitu sub faktor kerjasama standardisasi nasional dan kebijakan pengembangan prioritas sektor pembangunan (pengukuran dengan produk unggulan). Rincian dan nilai dari faktor dan sub faktor tersebut dapat dilihat pada Tabel 4 dan Tabel 5.

Indonesia termasuk negara ASEAN oleh karena itu kerjasama ASEAN dinilai lebih tinggi dilihat dari hubungan negara ASEAN khususnya ekonomi dan budaya. APEC yaitu kerjasama cekungan pacific yang meliputi Jepang, Amerika dan Negara Asia lainnya, mempunyai prospek yang besar setelah ASEAN, ASEM adalah kerjasama ASIA dan Eropa dianggap nilainya lebih rendah dibanding ASEAN dan APEC karena jarak transportasi yang jauh dibanding ASEAN dan prospek perdagangan masih rendah dari APEC.

Produk dikatakan produk unggulan yang mempunyai nilai ekspor tinggi. Produk unggulan dalam kelompok 16 besar mendapatkan nilai tinggi yaitu, 5 dan kelompok 50 besar nilai 3 dan diluar 50 besar mendapatkan nilai rendah yaitu, 1 .

Tabel 5 Kriteria dan Penilaian Faktor Kesesuaian dengan

Kebijakan Pengembangan Prioritas Sektor Pembangunan (Pengukuran dengan Produk Unggulan)

\begin{tabular}{|c|c|c|}
\hline No & Kelompok Produk Unggulan & Nilai \\
\hline 1 & Termasuk 16 besar & 5 \\
\hline 2 & Termasuk 50 besar & 3 \\
\hline 3 & Diluar 50 besar & 1 \\
\hline
\end{tabular}

\subsection{Ketersediaan Sumber Daya}

Ketersediaan sumber daya merupakan faktor penting yang dipertimbangkan dalam memilih TC karena nilai strategis dari faktor tersebut. Tingginya sumber daya alam menunjukkan potensi pengembangan untuk masa yang akan datang cukup baik. Ketersediaan sumber daya alam ini juga mencakup tingkat kemampuan dan penguasaan teknologi untuk mengolah sumber daya alam tersebut. Sumber daya alam yang banyak akan memberikan nilai tambah yang sedikit jika kemampuan teknologi pengolahan kita lemah.

Ketersediaan sumber daya manusia akan menentukan seberapa kemampuan kita untuk memberikan komentar dan masukan terhadap suatu draft standar yang dimintakan tanggapannya. Tanggapan tersebut akan memasukkan kepentingan-kepentingan nasional termasuk perbedaan nasional karena alasan geografis dan sosiografis yang berbeda dengan negara pengusul standar. Untuk mengadopsi semua kepentingan ini diperlukan tenaga ahli yang memadai. Disamping itu, satu tugas penting dari para ahli ini adalah mengusulkan standarstandar yang perlu dijadikan standar internasional dalam rangka melindungi produk dalam negeri terutama di pasaran internasional. Standar yang diusulkan juga dapat menjadi proteksi terhadap produk luar yang tidak sesuai atau yang dibawah standar untuk masuk ke Indonesia.

Rincian dan nilai dari kriteria tingkat ketersediaan sumber daya alam dan ketersediaan sumber daya manusia dapat dilihat pada Tabel 6 dan Tabel 7 .

Tabel 6 Kriteria dan Penilaian Faktor Ketersediaan Sumber Daya Alam

\begin{tabular}{|c|c|c|}
\hline No & $\begin{array}{c}\text { Sumber Daya Alam/Pemanfaatan Local } \\
\text { Content }\end{array}$ & Nilai \\
\hline 1 & Tinggi & 5 \\
\hline 2 & Sedang & 3 \\
\hline
\end{tabular}


Tabel 7 Kriteria dan Penilaian Faktor Kemampuan dan Ketersediaan SDM

\begin{tabular}{|c|c|c|}
\hline No & $\begin{array}{c}\text { Jumlah Tenaga Ahli dan Tingkat } \\
\text { Penguasaan Teknologi }\end{array}$ & Nilai \\
\hline 1 & Tersedia & 5 \\
\hline 2 & Terbatas & 3 \\
\hline 3 & Tidak ada & 1 \\
\hline
\end{tabular}

\subsection{Pembobotan Masing-masing Kriteria dan Sub Kriteria TC Produk}

Kriteria pemilihan TC Produk memiliki bobot kepentingan yang berbeda-beda. Keikutsertaan dan peran aktif Indonesia dalam suatau TC akan berpengaruh besar terhadap kepentingan produsen, sehingga faktor ini memiliki bobot terbesar. Artinya jika kepentingan produsen yang dilihat dari nilai ekspor besar, maka sangat dipertimbangkan keikutsertaan dalam ISO TC terkait. Hal ini dikarenakan efek berantai dari produsen yang jika produksi makin meningkat karena pasar yang meningkat, dengan sendirinya akan meningkatkan pendapatan negara dan pengaruh luasnya akan meningkatkan kehidupan ekonomi masyarakat.

Faktor-faktor lain setelah nilai ekspor adalah nilai impor (untuk perlindungan dan akomodasi kepentingan konsumen), disusul berturut-turut kerjasama standardisasi, produk ungulan dan ketersediaan SDM serta yang terakhir adalah ketersediaan SDA.

Pembahasan penentuan bobot dilakukan melalui Forum Group Discussion (FGD), diantara para pakar. Dihasilkan bahwa faktor atau kriteria kepentingan konsumen dengan sub faktor atau sub kriterianya nilai impor dianggap paling penting diantara kriteria yang ada, dan diberi bobot $25 \%$. Kepentingan produsen dalam wujud nilai impor dianggap kedua terbesar sehingga dihargai $20 \%$. Nilai ekspor yang tinggi akan menunjukkan keunggulan bersaing produk nasional di luar negeri, dan dengan kandungan lokal yang tinggi akan memberikan nilai tambah yang besar yang merupakan konstribusi kemakmuran rakyat. Kepentingan pemerintah adalah agar produk bernilai ekspor tinggi menjadi andalan atau produk unggulan nasional, diberi bobot $15 \%$. Dan mengingat dunia usaha kemungkinan mengalami hambatan bila melakukan sendiri dalam memperoleh pengakuan lulus uji antar negara, seperti moto "one standard, one test, accepted everywhere", maka pemerintah berkepentingan untuk memfasilitasi adanya kerjasama standardisasi antara berbagai negara yang mempunyai lab uji yang telah terakreditasi, sehingga kerjasama standardisasi diberi bobot $15 \%$. Selanjutnya ketersediaan sumber daya, baik manusai (SDM), maupun alam (SDA), maka untuk SDM dihargai 15\% karena dianggap lebih penting daripada SDA, dihargai $10 \%$. SDM merupakan potensi insani yang bila diberi motivasi yang kuat dan tepat akan menghasilkan kinerja yang luar biasa. SDA tanpa SDM tidak akan berarti apa-apa. Keseluruhan bobot bila dijumlah haruslah $100 \%$ dengan asumsi tidak ada faktor/kriteria lain diluar keempat yang ada yang dianggap dominan berpengaruh dalam pemilihan TC. Rincian bobot masing-masing faktor dapat dilihat pada Tabel 8 dibawah.

Rincian bobot masing-masing faktor dapat dilihat pada Tabel 8 dibawah.

Tabel 8 Pembobotan Masing-masing Kriteria Pemilihan TC Produk

\begin{tabular}{|l|l|l|c|}
\hline No & \multicolumn{1}{|c|}{ Kriteria } & \multicolumn{1}{c|}{ Sub Kriteria } & Bobot \\
\hline 1 & Kepentingan Konsumen & Nilai impor & 20 \\
\hline 2 & Kepentingan Produsen & Nilai ekspor & 25 \\
\hline 3 & Kepentingan pemerintah & Kerjasama standardisasi & 15 \\
\hline
\end{tabular}




\begin{tabular}{|l|l|l|c|}
\hline & & Produk unggulan & 15 \\
\hline \multirow{2}{*}{4} & Kepentingan pemerintah & SDA & 10 \\
\cline { 3 - 4 } & & SDM & 15 \\
\hline Total Bobot & $\mathbf{1 0 0}$ \\
\hline
\end{tabular}

\subsection{Kriteria untuk Pemilihan SC}

Setelah TC ISO didapatkan dengan memberikan passing grade tertentu, selanjutnya dilakukan pemilihan terhadap SC (Sub Committee) yang ada di bawah TC tersebut. Berbeda dengan pemilihan TC, pemilihan SC hanya akan menentukan apakah Indonesia akan mengikuti SC tersebut atau tidak mengikuti. Jika mengikuti harus diputuskan apakah mengikuti sebagai observer member saja atau mengikuti sebagai participant member. Parameter yang digunakan lebih kepada justifikasi kualitatif terhadap jenis bahasan yang dilakukan SC.

Jenis kajian atau pembahasan masingmasing SC dalam TC ada beberapa bagian yaitu tentang:
1. Istilah dan kosa kata

2. Produk inti maupun bagian-bagian atau turunan-turunannya.

3. Proses produksi yang langsung maupun yang mendukung.

4. Metode uji yang dilakukan untuk produk.

5. Masalah kesehatan, keselamatan, keamanan dan lingkungan (K3L), termasuk persyaratan, pencegahan dan penanganan dampak produk terhadap K3L.

Kriteria penentuan status keanggotaan SC ISO mengacu pada materi yang dibahas pada SC tersebut adalah seperti pada Tabel 9 di bawah.

Tabel 9 Kriteria Pemilihan SC untuk TC Terpilih

\begin{tabular}{|c|c|c|}
\hline No & Kajian/ bahasan pada SC ISO & Penilaian \\
\hline 1 & Istilah dan kosa kata & $\begin{array}{l}\text { a) Akan menjadi } \mathrm{P} \text { member jika Indonesia } \\
\text { menguasai bidang tersebut atau menjadi } \\
\text { market leader } \\
\text { b) Akan menjadi O member jika Indonesia } \\
\text { menguasai bidang tersebut tetapi tidak } \\
\text { menjadi market leader } \\
\text { c) Jika Indonesia tidak menguasai bidang } \\
\text { statusnya non member. }\end{array}$ \\
\hline 2 & $\begin{array}{l}\text { Produk inti maupun bagian-bagian atau turunan- } \\
\text { turunannya. }\end{array}$ & $\begin{array}{l}\text { a) Akan menjadi P member jika bagi } \\
\text { Indonesia menjadi prioritas pengembangan } \\
\text { b) Jika tidak menjadi prioritas, statusnya tidak } \\
\text { jadi member }\end{array}$ \\
\hline 3 & $\begin{array}{l}\text { Proses produksi yang langsung maupun yang } \\
\text { mendukung. }\end{array}$ & $\begin{array}{l}\text { a) Akan menjadi P member jika perkem- } \\
\text { bangan industri proses ini dinamis } \\
\text { b) Jika tidak dinamis, statusnya jadi O- } \\
\text { member }\end{array}$ \\
\hline 4 & Metode uji yang dilakukan untuk produk & $\begin{array}{l}\text { a) Akan menjadi } \mathrm{P} \text { member jika terkait lang- } \\
\text { sung dengan produk/sub produk } \\
\text { b) Jika tidak terkait langsung dengan } \\
\text { produk/sub produk statusnya jadi O mem- } \\
\text { ber }\end{array}$ \\
\hline 5 & $\begin{array}{l}\text { Masalah kesehatan, keselamatan, keamanan dan } \\
\text { lingkungan (K3L) }\end{array}$ & Member \\
\hline
\end{tabular}

\section{PENILAIAN DAN ANALISIS}

\subsection{Penilaian TC Produk Terpilih}

Berdasarkan data ISO/TC, ISO TC yang terkait produk logam sebanyak $15 \mathrm{TC}$, ISO/TC terkait produk mesin sebanyak 20 TC dan kendaraan bermotor sebanyak $10 \mathrm{TC}$.
Kemudian dari TC tersebut dilakukan penilaian dan perhitungan dengan memasukkan faktor bobot untuk masing-masing kriteria, didapatkan peringkat TC sesuai dengan urutan dari nilai terbesar ke yang lebih kecil seperti pada Lampiran. 
Untuk TC Produk diambil passing grade nilai sebesar 2,1 . Nilai ini digunakan sebagai batas pemilihan karena satu tingkat nilai dibawahnya yaitu 2 hanya $1 \mathrm{TC}$, sedangkan jika elimi- nasi melibat TC dengan nilai 2,1 maka ada 2 TC yang dieleminiasi. Ternyata dengan batas nilai 2,1 didapatkan 10 TC terpilih (Tabel 10).

Tabel 10 Sepuluh TC Terpilih Berdasarkan Ranking

\begin{tabular}{|l|l|l|c|}
\hline No & No TC & \multicolumn{1}{|c|}{ Nama TC } & Jumlah \\
\hline 1 & TC22 & Road vehicle & 3 \\
\hline 2 & TC31 & Tyres, rims, and valves & 2.9 \\
\hline 3 & TC8 & Ships and marine technology & 2.6 \\
\hline 4 & TC183 & Copper, lead, zinc and nickel ores and concentrates & 2.6 \\
\hline 5 & TC26 & Copper and copper alloys & 2.4 \\
\hline 6 & TC39 & Machine tools & 2.4 \\
\hline 7 & TC110 & Industrial trucks & 2.4 \\
\hline 8 & TC67 & $\begin{array}{l}\text { Materials, equipment and offshore structures for petro- } \\
\text { leum, petrochemical and natural gas industries }\end{array}$ & 2.3 \\
\hline 9 & TC178 & Lifts, escalators, passenger conveyors & 2.1 \\
\hline 10 & TC119 & Powder metallurgy & 2.1 \\
\hline
\end{tabular}

\subsection{Usul Status Keanggotaan Indonesia dalam SC/ISO}

Setelah dilakukan penilaian terhadap TC terpilih, diusulkan status keanggotaan Indonesia dalam SC/ISO yang merupakan turunan (Sub Committee) dari Komite Teknis (TC)/ISO tersebut. Dalam usulan ini meski dalam beberapa SC pada TC yang sama terdapat $P$ member dan $O$ member, namun di TC nya tetap bebas, dapat berstatus $P$ member atau $O$ member, namun sebaiknya otomatis berstatus $P$ member di TC tersebut.

Berdasarkan penilaian SC dari 10 TC terpilih (Tabel 11), diketahui bahwa pada:

- TC 22 Road Vehicle, status keanggotaan Indonesia sebelumnya adalah $O$ member. Berdasarkan hasil penilaian maka usulan keanggotaan Indonesia untuk $P$ member sebanyak 14 SC, O member sebanyak 6 SC dan non member sebanyak 3 SC.

- TC 31 Tyre, Rims and Valve, status keanggotaan Indonesia sebelumnya adalah $O$ member. Berdasarkan hasil penilaian maka usulan keanggotaan Indonesia untuk $P$ member sebanyak $6 \mathrm{SC}$, dan non member sebanyak 2 SC.

- TC 8 Ship and Marine Technology, sebelumnya Indonesia tidak menjadi anggota namun berdasarkan hasil penilaian maka usulan keanggotaan Indonesia untuk
$P$ member sebanyak $3 \mathrm{SC}$, O member sebanyak 2 SC dan non member sebanyak 6 SC.

- TC 183 Copper, Lead, Zinc and Nickel Ores and Concentrates, status keanggotaan Indonesia sebelumnya adalah $O$ member. TC 183 tidak mempunyai SC, berdasarkan hasil penilaian usulan keanggotaan Indonesia untuk TC tersebut tetap $O$ member.

- TC 26 Copper and Copper Alloys, status keanggotaan Indonesia sebelumnya adalah O member. TC 26 tidak mempunyai SC, berdasarkan hasil penilaian usulan keanggotaan Indonesia untuk TC tersebut tetap $O$ member.

- TC 39 Machine Tools, status keanggotaan Indonesia sebelumnya adalah $O$ member. Berdasarkan hasil penilaian maka usulan keanggotaan Indonesia adalah $P$ member untuk SC 2, O member untuk SC 6 dan SC 10 dan non member SC 4 dan SC 8.

- TC 110 Industrial Trucks, sebelumnya Indonesia tidak menjadi anggota namun berdasarkan hasil penilaian maka usulan keanggotaan Indonesia adalah $O$ member untuk SC 2 dan SC 3 dan non member untuk SC 1.

- TC 67 Materials, Equipment and Offshore Structures for Petroleum, Petrochemical and 
Natural Gas Industries, status keanggotaan Indonesia sebelumnya adalah $P$ member. Berdasarkan hasil penilaian maka usulan keanggotaan Indonesia adalah $P$ member untuk semua SC.

- TC 178 Lifts, Escalators, Passenger Conveyors, status keanggotaan Indonesia sebelumnya adalah $O$ member. TC 178 tidak mempunyai SC, berdasarkan hasil penilaian usulan keanggotaan Indonesia untuk TC tersebut tetap $P$ member karena berkaitan dengan aspek keamanan dan keselamatan.

- TC 119 Powder Metallurgy, sebelumnya Indonesia tidak menjadi anggota namun berdasarkan hasil penilaian maka usulan keanggotaan Indonesia adalah $P$ member untuk SC 2 dan SC 5 dan $O$ member untuk SC 3 dan SC 4.

\section{KESIMPULAN}

Usulan keanggotan Indonesia pada ISO/TC dan SC sebagai berikut:

- TC 22 Road Vehicle, usulan keanggotaan Indonesia untuk $P$ member sebanyak 14 SC, O member sebanyak 6 SC dan non member sebanyak 3 SC.

- TC 31 Tyre, Rims dan Valve, usulan keanggotaan Indonesia untuk $P$ member sebanyak $6 \mathrm{SC}$, dan non member sebanyak 2 SC.

- TC 8 Ship and Marine Technology, usulan keanggotaan Indonesia untuk $P$ member sebanyak 3 SC, $O$ member sebanyak 2 SC dan non member sebanyak 6 SC.
- TC 183 Copper, Lead, Zinc and Nickel Ores and Concentrates, usulan keanggotaan Indonesia untuk TC tersebut tetap $O$ member.

- TC 26 Copper and Copper Alloys, usulan keanggotaan Indonesia untuk TC tersebut tetap O member.

- TC 39 Machine Tools, usulan keanggotaan Indonesia adalah $P$ member untuk SC 2, $O$ member untuk SC 6 dan SC 10 dan non member SC 4 dan SC 8.

- TC 110 Industrial Trucks, usulan keanggotaan Indonesia adalah $O$ member untuk SC 2 dan SC 3 dan non member untuk SC 1.

- TC 67 Materials, Equipment and Offshore Structures for Petroleum, Petrochemical and Natural Gas Industries, usulan keanggotaan Indonesia adalah $P$ member untuk semua $\mathrm{SC}$.

- TC 178 Lifts, Escalators, Passenger Conveyors, usulan keanggotaan Indonesia untuk TC tersebut tetap $P$ member karena berkaitan dengan aspek keamanan dan keselamatan.

- TC 119 Powder Metallurgy, usulan keanggotaan Indonesia adalah $P$ member untuk SC 2 dan SC 5 dan $O$ member untuk SC 3 dan SC 4. 
Tabel 11 Usulan Keanggotan SC ISO dalam TC Produk Terpilih

\begin{tabular}{|c|c|c|c|c|c|c|}
\hline No. & No TC & Nama TC & No SC & Nama SC & $\begin{array}{l}\text { Usulan Status } \\
\text { Keanggotaan }\end{array}$ & Alasan Penilaian \\
\hline \multirow[t]{23}{*}{1} & \multirow[t]{23}{*}{ TC22 } & \multirow{23}{*}{$\begin{array}{l}\text { Road vehicle } \\
\text { (sebelumnya } \\
\text { O-member) }\end{array}$} & SC1 & Ignition equipment & P-member & (2a) Prioritas \\
\hline & & & SC2 & Braking systems and equipment & P-member & (2a) prioritas \\
\hline & & & SC3 & Electrical and electronic equipment & P-member & (2a) prioritas \\
\hline & & & SC4 & Caravans and light trailers & Non & (2b) tidak prioritas \\
\hline & & & SC5 & Engine tests & P-member & $\begin{array}{l}\text { (4a) terkait langsung } \\
\text { produk }\end{array}$ \\
\hline & & & SC6 & $\begin{array}{l}\text { Terms and definitions of dimensions } \\
\text { and masses }\end{array}$ & O-member & $\begin{array}{l}\text { (1c) tidak menguasa } \\
\text { bidang }\end{array}$ \\
\hline & & & SC7 & $\begin{array}{l}\text { Injection equipment and filters for use } \\
\text { on road vehicles }\end{array}$ & P-member & (2a) prioritas \\
\hline & & & SC8 & Lighting and signaling & P-member & (2a) prioritas \\
\hline & & & SC9 & $\begin{array}{l}\text { Vehicle dynamics and road-holding } \\
\text { ability }\end{array}$ & P-member & (2a) prioritas \\
\hline & & & SC10 & Impact test procedures & P-member & $\begin{array}{l}\text { (4a) terkait langsung } \\
\text { produk }\end{array}$ \\
\hline & & & SC11 & Safety glazing materials & O-member & $\begin{array}{l}\text { (4b) tidak terkait } \\
\text { langsung produk }\end{array}$ \\
\hline & & & SC12 & Passive safety crash protection systems & O-member & $\begin{array}{l}\text { (4b) tidak terkait } \\
\text { langsung produk }\end{array}$ \\
\hline & & & SC13 & Ergonomics applicable to road vehicles & P-member & $\begin{array}{l}\text { (4a) terkait langsung } \\
\text { produk }\end{array}$ \\
\hline & & & SC14 & Exterior fittings & Non & (2b) tidak prioritas \\
\hline & & & SC15 & $\begin{array}{l}\text { Interchangeability of components of } \\
\text { commercial vehicles and buses }\end{array}$ & P-member & (2a) prioritas \\
\hline & & & SC16 & Reduction of fire risks & O-member & $\begin{array}{l}\text { (4b) tidak terkait } \\
\text { langsung dengan } \\
\text { produk }\end{array}$ \\
\hline & & & SC17 & Visibility & O-member & $\begin{array}{l}\text { (4b) tidak terkait } \\
\text { langsung dengan } \\
\text { produk }\end{array}$ \\
\hline & & & SC19 & Wheels & P-member & (2a) prioritas \\
\hline & & & SC21 & Electric road vehicles & P-member & (2a) prioritas \\
\hline & & & SC22 & Motorcycles & P-member & (2a) prioritas \\
\hline & & & SC23 & Mopeds & Non & (2b) tidak prioritas \\
\hline & & & SC25 & Road vehicles using natural gas & P-member & (2b) prioritas \\
\hline & & & SC26 & $\begin{array}{l}\text { Accessibility of vehicles to the } \\
\text { physically handicapped }\end{array}$ & O-member & $\begin{array}{l}\text { (4b) tidak terkait } \\
\text { langsung dengan } \\
\text { produk }\end{array}$ \\
\hline \multirow[t]{8}{*}{2} & \multirow[t]{8}{*}{ TC31 } & \multirow{8}{*}{\begin{tabular}{|l|} 
Tyres, rims, \\
and valves \\
(sebelumnya \\
O-member)
\end{tabular}} & SC3 & Passenger car tyres and rims & P-member & (2a) prioritas \\
\hline & & & SC4 & Truck and bus tyres and rims & P-member & (2a) prioritas \\
\hline & & & SC5 & Agricultural tyres and rims & P-member & (2a) prioritas \\
\hline & & & SC6 & Off-the-road tyres and rims & Non & (2b) tidak prioritas \\
\hline & & & SC7 & Industrial tyres and rims & P-member & $\begin{array}{l}\text { (3a) Perkembangan } \\
\text { industri dinamis }\end{array}$ \\
\hline & & & SC8 & Aircraft tyres and rims & Non & (2b) tidak prioritas \\
\hline & & & SC9 & Valves for tube and tubeless tyres & P-member & (2a) prioritas \\
\hline & & & SC10 & $\begin{array}{l}\text { Cycle, moped, motorcycle tyres and } \\
\text { rims }\end{array}$ & P-member & (2a) prioritas \\
\hline
\end{tabular}




\begin{tabular}{|c|c|c|c|c|c|c|}
\hline No. & No TC & Nama TC & No SC & Nama SC & $\begin{array}{l}\text { Usulan Status } \\
\text { Keanggotaan }\end{array}$ & Alasan Penilaian \\
\hline \multirow[t]{11}{*}{3} & \multirow[t]{8}{*}{ TC8 } & \multirow{8}{*}{$\begin{array}{l}\text { Ships and } \\
\text { marine } \\
\text { technologi } \\
\text { (sebelumnya } \\
\text { tidak terdaftar } \\
\text { P/O-member) }\end{array}$} & SC1 & Lifesaving and fire protection & P-member & $\begin{array}{l}\text { (4a) terkait langsung } \\
\text { produk }\end{array}$ \\
\hline & & & SC2 & Marine environment protection & P-member & (5) terkait lingkungan \\
\hline & & & SC3 & Piping and machinery & 0-member & (2a) prioritas \\
\hline & & & SC4 & Outfitting and deck machinary & Non & (2b) tidak prioritas \\
\hline & & & SC5 & Ships' bridge layout & Non & (2b) tidak prioritas \\
\hline & & & SC6 & Navigation & Non & (2b) tidak prioritas \\
\hline & & & SC7 & Inland navigation vessels & Non & (2b) tidak prioritas \\
\hline & & & SC8 & Structures & Non & (2b) tidak prioritas \\
\hline & & & SC9 & General requirements & P-member & (2a) prioritas \\
\hline & & & SC10 & Computer applications & O-member & $\begin{array}{l}\text { (4b) tidak terkait } \\
\text { langsung dengan } \\
\text { produk }\end{array}$ \\
\hline & & & SC11 & Intermodal and short sea shipping & Non & (2b) tidak prioritas \\
\hline 4 & TC183 & $\begin{array}{l}\text { Copper, lead, } \\
\text { zinc and nickel } \\
\text { ores and } \\
\text { concentrates } \\
\text { (sebelumnya } \\
\text { O-member) }\end{array}$ & & Tidak ada SC & O member & (2b) tidak prioritas \\
\hline 5 & TC 26 & $\begin{array}{l}\text { Copper and } \\
\text { copper alloys } \\
\text { (sebelumnya } \\
\text { tidak terdaftar } \\
\text { P/O-member) }\end{array}$ & & Tidak ada SC & O-member & (2b) tidak prioritas \\
\hline \multirow[t]{5}{*}{6} & \multirow[t]{5}{*}{ TC 39} & \multirow{5}{*}{$\begin{array}{l}\text { Machine tools } \\
\text { (sebelumnya } \\
\text { O-member) }\end{array}$} & SC2 & $\begin{array}{l}\text { Test conditions for metal cutting } \\
\text { machine tools }\end{array}$ & P-member & $\begin{array}{l}\text { (4a) terkait langsung } \\
\text { produk }\end{array}$ \\
\hline & & & SC4 & Woodworking machines & Non & (2a) tidak prioritas \\
\hline & & & SC6 & Noise of machine tools & O-member & $\begin{array}{l}\text { (4b) tidak terkait } \\
\text { langsung produk }\end{array}$ \\
\hline & & & SC8 & Work holding spindles and chucks & Non & (2a) tidak prioritas \\
\hline & & & SC10 & Safety & O-member & $\begin{array}{l}\text { (4b) tidak terkait } \\
\text { langsung produk }\end{array}$ \\
\hline \multirow[t]{3}{*}{7} & \multirow[t]{3}{*}{ TC110 } & \multirow{3}{*}{$\begin{array}{l}\text { Industrial } \\
\text { trucks } \\
\text { (sebelumnya } \\
\text { tidak terdaftar } \\
\text { P/O-member) }\end{array}$} & SC1 & General Terminology & Non & $\begin{array}{l}\text { (1c) tidak menguasai } \\
\text { bidang }\end{array}$ \\
\hline & & & SC2 & Safety of powered industrial trucks & O-member & $\begin{array}{l}\text { (4b) tidak terkait } \\
\text { langsung produk }\end{array}$ \\
\hline & & & SC3 & Industrial wheels and castors & O-member & $\begin{array}{l}\text { (3b) perkembangan } \\
\text { industri tidak dinamis }\end{array}$ \\
\hline \multirow[t]{6}{*}{8} & \multirow[t]{6}{*}{ TC67 } & \multirow{6}{*}{$\begin{array}{l}\text { Materials, } \\
\text { equipment and } \\
\text { offshore } \\
\text { structures for } \\
\text { petroleum, } \\
\text { petrochemical } \\
\text { and natural gas } \\
\text { industries } \\
\text { (sebelumnya } \\
\text { P-member) }\end{array}$} & SC2 & Pipeline transportation systems & P-member & (2a) prioritas \\
\hline & & & SC3 & $\begin{array}{l}\text { Drilling and completion fluids, and well } \\
\text { cements }\end{array}$ & P-member & (2a) prioritas \\
\hline & & & $\mathrm{SC} 4$ & Drilling and production equipment & P-member & (2a) prioritas \\
\hline & & & SC5 & Casing, tubing and drill pipe & P-member & (2a) prioritas \\
\hline & & & SC6 & Processing equipment and systems & P-member & (2a) prioritas \\
\hline & & & SC7 & Offshore structures & P-member & (2a) prioritas \\
\hline 9 & TC 178 & $\begin{array}{l}\text { Lifts, } \\
\text { escalators, } \\
\text { passenger } \\
\text { conveyors } \\
\text { (sebelumnya } \\
\text { O-member) }\end{array}$ & - & & P member & $\begin{array}{l}\text { (5) masalah } \\
\text { kesehatan, } \\
\text { keselamatan, } \\
\text { keamanan dan } \\
\text { lingkungan (K3L ) }\end{array}$ \\
\hline 10 & TC 119 & $\begin{array}{l}\text { Powder } \\
\text { metallurgy } \\
\text { (sebelumnya }\end{array}$ & SC 2 & $\begin{array}{l}\text { Sampling and testing methods for } \\
\text { powders (including powders for } \\
\text { hardmetals) }\end{array}$ & P-member & $\begin{array}{l}\text { (4a) terkait langsung } \\
\text { dengan produk }\end{array}$ \\
\hline
\end{tabular}




\begin{tabular}{|l|l|l|l|l|l|l|}
\hline No. & \multirow{2}{*}{ No TC } & Nama TC & No SC & Nama SC & $\begin{array}{l}\text { Usulan Status } \\
\text { Keanggotaan }\end{array}$ & Alasan Penilaian \\
\hline \multirow{2}{*}{} & & $\begin{array}{l}\text { tidak terdaftar } \\
\text { P/O-member) }\end{array}$ & SC 3 & $\begin{array}{l}\text { Sampling and testing methods for } \\
\text { sintered metal materials (excluding } \\
\text { hardmetals }\end{array}$ & O-member & $\begin{array}{l}\text { (4b) tidak terkait } \\
\text { langsung dengan } \\
\text { produk }\end{array}$ \\
\cline { 3 - 6 } & & SC 4 & $\begin{array}{l}\text { Sampling and testing methods for } \\
\text { hardmetals }\end{array}$ & O-member & $\begin{array}{l}\text { (4b) tidak terkait } \\
\text { langsung dengan } \\
\text { produk }\end{array}$ \\
\cline { 3 - 6 } & & SC 5 & $\begin{array}{l}\text { Specifications for powder metallurgical } \\
\text { materials (excluding hardmetals) }\end{array}$ & P-member & (2a) prioritas \\
\hline
\end{tabular}

\section{DAFTAR PUSTAKA}

1 Waluyo, P., Hilman, MS, 2004. "Kajian Kondisi Industri dan Perdagangan Produk Logam, Mesin, dan Alat Angkut dalam Kaitannya dengan Keanggotaan Indonesia pada Komite Teknis (Technical Committee) dari International Organization for Standardization (ISO/TC.)", Jurnal Standardisasi Vol. 6 No. 3 November 2004, Badan Standardisasi Nasional, Jakarta

2 Suciati, R., 2006. "Kajian Perkembangan Perdagangan Karet Indonesia ke Negara Anggota ISO/TC 45", Jurnal Standardisasi Vol. 8 No. 1 Maret 2006, Badan Standardisasi Nasional, Jakarta

3 BSN, 2000. "Standardisasi dalam Perspektif IImu, Industri dan Perdagangan", Badan Standardisasi Nasional, Jakarta

4 Pusdatin, 2004. "Data Industri dan Perdagangan Tahun 1999 s.d. 2003", Pusat Data Industri (Pusdatin), Jakarta
5 ISO, 2000. "Memento ISO"

6 BPS, 2003. "Statistik Indonesia 2002", Badan Pusat Statistik, Jakarta.

7 http://www.iso.org/iso/en/aboutiso

\section{BIODATA}

Ir. Prihadi Waluyo, MM adalah lulusan Teknik Industri ITB yang kemudian melanjutkan jenjang S2 di Magister Menejemen Bisnis dan Administrasi Teknologi ITB. Penulis saat ini bekerja di Pusat Penelitian dan Pengembangan Standardisasi BSN.

Muti Sophira Hilman, menamatkan pendidikan di Universitas Padjajaran, jurusan Biologi. Saat ini penulis bekerja di Badan Standardisasi Nasional sebagai peneliti pada Pusat Penelitian dan Pengembangan Standardisasi. 
